\title{
El principio de \\ culpabilidad en el \\ derecho administrativo \\ sancionador, con especial \\ mirada al caso peruano
}

\author{
Víctor Sebastián Baca Oneto ${ }^{1}$
}

\section{RESUMEN}

En este trabajo se analiza el alcance del principio de culpabilidad como uno de los pilares del derecho administrativo sancionador. Se abordan los supuestos en que la aplicación de este principio puede resultar más controvertida, como es el caso de la responsabilidad de las personas jurídicas y las infracciones de mero desconocimiento. De acuerdo con la investigación realizada, no es posible prescindir de la aplicación de este principio, más allá de que existan peculiaridades en su aplicación, entre las cuales se destaca la inversión de la carga de la prueba.

Palabras clave: sanción administrativa, infracción administrativa, principio de culpabilidad, responsabilidad objetiva, responsabilidad de las personas jurídicas.

1 Profesor ordinario principal, director del programa académico de Derecho en Campus Lima y de la Maestría en Derecho Administrativo y Regulación del Mercado, Universidad de Piura, Lima, Perú. Vocal de la Sala de Eliminación de Barreras Burocráticas del Tribunal del Instituto Nacional de Defensa de la Competencia y Protección de la Propiedad Intelectual (INDECOPI); Of. Counsel y jefe del área de Derecho Público de la Oficina de Garrigues, Lima, Perú. Abogado por la Universidad de Piura, Piura, Perú. Doctor en Derecho por la Universidad de Valladolid, Valladolid, España. Correo-e: victor.baca@udep.pe. Enlace ORCID: https://orcid.org/0000-0001-8644-7425. Fecha de recepción: 15 de agosto de 2018. Fecha de modificación: $1{ }^{\circ}$ de septiembre de 2018. Fecha de aceptación: 24 de septiembre de 2018. Para citar el artículo: Baca Oneto, Víctor Sebastián, "El principio de culpabilidad en el derecho administrativo sancionador, con especial referencia al derecho peruano", Revista digital de Derecho Administrativo, Universidad Externado de Colombia, n. ${ }^{\circ}$ 21, 2019, pp. 313-344. DOI: https://doi.org/10.18601/21452946.n21.13 


\title{
Principle of Liability in Administrative Sanctioning Procedures, with Particular Regard to the Peruvian Case
}

\begin{abstract}
This paper analyzes the extent of the principle of liability as one of the main principles governing administrative sanctioning procedures. It examines those cases were the application of this principle has been controversial, such as the liability of legal entities or the mere breach of a legal or regulatory duty. Despite noticing some particularities in the application of the principle of liability, like the overturn of the burden of proof, this research concludes that is not possible to disregard this principle in administrative sanctioning procedures.

Keywords: Administrative Sanction, Breach of an Administrative Duty, Principle of Liability, Strict Liability, Liability of Legal Entities.
\end{abstract}

\section{A MODO DE INTRODUCCIÓN. LA UNIDAD DEL IUS PUNIENDI Y LA APLICACIÓN DE LOS PRINCIPIOS DE ESTE AL DERECHO ADMINISTRATIVO SANCIONADOR}

\begin{abstract}
Al momento de estudiar el derecho administrativo sancionador es necesario empezar la casa por el tejado². Es decir, la mejor manera de entenderlo es reconocer lo que es una sanción, la cual se define como una medida con un fin aflictivo ${ }^{3}$. Evidentemente, las sanciones pueden buscar finalidades diferentes a la puramente punitiva, como pueden ser la prevención general o la
\end{abstract}

2 Similar construcción, que reconduce los principios del derecho administrativo sancionador a la noción de castigo, en Manuel Rebollo PuiG, "Derecho penal y derecho administrativo sancionador (principios comunes y aspectos diferenciadores)", en Diccionario de sanciones administrativas, Madrid: Iustel, 2010, pp. 317 y ss. Como bien dice este autor, "la institución central, definitoria y originaria del derecho penal es la pena, no el delito [...]. Conceptualmente, la pena es anterior al delito" (p. 318).

3 José Suay Rincón, Sanciones administrativas, Bolonia: Publicaciones del Real Colegio de España, 1989, pp. 167 y ss.; y, del mismo autor, "Concepto de sanción", en Diccionario de sanciones administrativas, Madrid: Iustel, 2010, pp.170-171. No debe confundirse el "contenido aflictivo", que puede ser común a otras formas de reacción que prevé el ordenamiento jurídico ante una conducta ilícita, con el "fin aflictivo", que es propio de las sanciones. Al respecto, por ejemplo, Manuel ReBollo Puig, "Derecho penal y derecho administrativo sancionador...", óp. cit., p. 317; y "El contenido de las sanciones", Revista Justicia Administrativa, número extraordinario, Valladolid: Lex Nova, 2001, pp. 155 y ss. La importancia del "fin aflictivo" en las sanciones fue puesta de relieve tiempo atrás por SeBASTIÁN MARTín Retortillo, "Multas administrativas", Revista de Administración Pública, n. ${ }^{\circ}$ 79, Madrid: Centro de Estudios Políticos y Constitucionales, 1976, p. 10. 
prevención especial, entre otras. Sin embargo, dicha finalidad punitiva no puede faltar nunca.

Es muy habitual indicar que el derecho penal cumple una finalidad represiva, mientras que el derecho administrativo sancionador tiene finalidad preventiva. Así, por ejemplo, en palabras de Miriam Cueto,

el derecho penal trata de defender bienes jurídicos [... y de hacer un juicio de reproche al sujeto que ha cometido una falta o delito, mientras que el derecho administrativo sancionador trata de proteger el cumplimiento del ordenamiento jurídico en aras del interés general que legitima la actuación administrativa, por ello cumple con una clara función preventiva, sin que exista ningún interés en el reproche moral al individuo ${ }^{4}$.

Es cierto que el derecho administrativo sancionador tiene una finalidad preventiva, pero esta no es exclusiva de este, sino que también se extiende al derecho penal ${ }^{5}$. Tampoco se excluye que también en derecho administrativo sancionador solo quepa una sanción si se han afectado o puesto en riesgo bienes jurídicos, dado que la antijuridicidad es también un requisito de la infracción ${ }^{6}$. Además, el "reproche" que se hace desde el derecho penal a una conducta tampoco es moral, sino jurídico ${ }^{7}$, y no puede faltar en ningún caso en que se impone un castigo. En este sentido, debe tomarse en cuenta que el carácter preventivo que se le atribuye al derecho administrativo sancionador no altera su naturaleza ni puede servir como fundamento para una diferencia cualitativa entre las infracciones y los delitos, como algunos sostienen ${ }^{8}$.

4 Miriam Cueto Pérez, "Los principios de la potestad sancionadora de la Administración pública. Tipicidad y responsabilidad", Documentación Administrativa, n. ${ }^{\circ}$ 280-281, Madrid: INAP, 2008, p. 108. En el mismo sentido, ÁnGeles de PALMA DEL TeSO, El principio de culpabilidad en el derecho administrativo sancionador, Madrid: Tecnos, 1996, pp. 41 y ss. Más recientemente, de la misma autora, "Principio de culpabilidad. Definición y aplicación a las personas físicas", en Diccionario de sanciones administrativas, Madrid: Iustel, 2010, pp. 705-706.

5 En el caso de la admisión de la responsabilidad penal de las personas jurídicas, esta finalidad preventiva está especialmente patente. Véase MANuEL GÓMEZ TOMILLO, Introducción a la responsabilidad penal de las personas jurídicas en el sistema español, Valladolid: Lex Nova, 2010, pp. 23 y ss.

6 Como se explica Manuel Rebollo Puig, "Antijuridicidad", en Diccionario de sanciones administrativas, Madrid: lustel, 2010, pp. 119 y ss., la antijuridicidad es también una nota que define a las infracciones administrativas (véase nota 50).

7 Manuel Gómez Tomillo e IÑigo Sanz Rubiales, Derecho administrativo sancionador. Parte general. Teoría y práctica del derecho penal administrativo, 4. ${ }^{a}$ ed., Madrid: Thomson Reuters - Aranzadi, 2017, pp. 433 y ss.

8 Por ejemplo, Miguel CaSino Rubio, "La potestad sancionadora de la Administración y vuelta a la casilla de salida", Documentación administrativa, Nueva Época, nº. 2, Madrid: INAP,

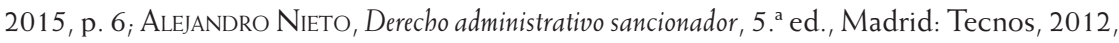
p. 148. 
Así, lo que define a las sanciones no es la finalidad preventiva, sino la forma en que se aplica esta finalidad preventiva: castigando'. Y este es el fundamento de la unidad del ius puniendi estatal: la idéntica naturaleza de castigo que tienen las penas y las sanciones. Por tanto, la sanción es un castigo, ya sea que la imponga la Administración o la imponga un juez. En ambos casos estamos ante el ejercicio de potestades "punitivas" por parte del poder público, de allí que sea común referirse al ius puniendi estatal, que es ejercido por los jueces cuando castigan las conductas consideradas como delictivas, y por la Administración cuando castiga las que son consideradas como infracciones. No obstante, lo que en ningún caso debe perderse de vista es que en ambos casos se trata de castigos.

De esta manera, es más fácil entender la famosa unidad del ius puniendi estatal, y comprender por qué no existe -pese a que en algún momento se sostuvo lo contrario- una distinción cualitativa entre el ejercicio de las potestades punitivas por los jueces y por la Administración pública. Sin importar quién sea el que imponga el castigo -y más allá de que existen ciertas peculiaridades en uno y otro ámbito, producto de los bienes jurídicos protegidos y del diferente papel que juega en el procedimiento la Administración del que cumplen los jueces ${ }^{10}$ - se trata de un castigo. En consecuencia, deben aplicarse una serie de principios comunes, que en el caso peruano han sido enumerados en el artículo 246 del Texto Único Ordenado de la Ley 27444, Ley del Procedimiento Administrativo General, aprobado mediante el Decreto Supremo 006-2017-Jus (en adelante, LPAG) $)^{11}$.

Es decir, no se trata de principios del derecho penal que se aplican al derecho administrativo, sino que son principios del ejercicio de la potestad sancionadora, que tradicionalmente se han estudiado en el derecho penal, debido a que hasta hace no mucho se entendía que los jueces debían tener el

9 En este sentido, Tomás Cano Campos, "¿Es una sanción la retirada del carnet por puntos?", Revista de Administración Pública, n. ${ }^{\circ} 184$, Madrid: Centro de Estudios Políticos y Constitucionales, 2011, p. 107.

10 Sobre las diferencias entre el derecho penal y el derecho administrativo sancionador véase, por ejemplo, Manuel Rebollo Puig, "Derecho penal y derecho administrativo sancionador...", óp. cit., pp. 324 y ss. Al respecto, es ilustrativa la afirmación de Lucía Alarcón Sotomayor, para quien existe una identidad ontológica entre delito e infracción, y entre pena y sanción, pero "sí que existen diferencias -y sobresalientes- entre la Administración y los jueces penales, entre el derecho penal y el derecho administrativo sancionador; $\mathrm{y}$ entre el proceso penal y el procedimiento administrativo sancionador". LuCíA AlarCón SотOMAYOR, "Los confines de las sanciones: en busca de la frontera entre derecho penal y derecho administrativo sancionador", Revista de Administración Pública, n. ${ }^{\circ} 195$, Madrid: Centro de Estudios Políticos y Constitucionales, 2014, pp. 145 y ss.

11 El texto original de la Ley 27444 fue publicado el 11 de abril de 2001. En adelante, cuando hagamos referencia a las modificaciones introducidas en esta norma, aludiremos a las introducidas por el Decreto Legislativo 1272, del 21 de diciembre de 2016. 
monopolio de la imposición de $\operatorname{castigos}^{12}$, pero que son igualmente aplicables a las otras manifestaciones de dicha potestad, también cuando la ejerce la Administración pública. Esta unidad es la que explica que, por ejemplo, en ordenamientos jurídicos como el alemán, las sanciones administrativas sean impugnables en la vía penal y no en la contencioso administrativa, como correspondería al haber sido impuestas mediante actos administrativos. Sin embargo, esta identidad en cuanto a la naturaleza de la potestad ejercida no debe llevarnos a afirmar la total identidad entre el derecho administrativo sancionador y el derecho penal, pues existen numerosas diferencias, no solo en la forma en que dichos principios se aplican, sino en cuestiones procedimentales, de no poca importancia ${ }^{13}$.

La sanción se define, por tanto, como una medida con un fin aflictivo, que no únicamente busca reponer las cosas a un estado anterior, sino que busca imponer un castigo, causar un nuevo mal a quien hubiera sido responsable de

12 Eduardo García de Enterría, "El problema jurídico de las sanciones administrativas", Revista Española de Derecho Administrativo, n. ${ }^{\circ} 10$, Madrid: Civitas, 1976, pp. 399 y ss.; y RAMÓn PARADA VÁZQuEZ, "El poder sancionador de la Administración y la crisis del sistema judicial penal", Revista de Administración Pública, n. ${ }^{\circ}$ 67, Madrid: Centro de Estudios Políticos y Constitucionales, 1972, pp. 41 y ss. Sobre el fundamento en virtud del cual puede una Administración pública imponer un castigo, resulta especialmente esclarecedora la cita a la Sentencia del Tribunal Constitucional Español 77/1983, del 3 de octubre de 1983, según la cual: "No cabe duda de que en un sistema en que rigiera de manera estricta y sin fisuras la división de los poderes del Estado, la potestad sancionadora debería constituir un monopolio judicial y no podría estar nunca en manos de la Administración, pero un sistema semejante no ha funcionado nunca históricamente y es lícito dudar que fuera incluso viable, por razones que no es ahora momento de exponer con detalle, entre las que se pueden citar la conveniencia de no recargar en exceso las actividades de la Administración de justicia como consecuencia de ilícitos de gravedad menor, la conveniencia de dotar de una mayor eficacia al aparato represivo en relación con ese tipo de ilícitos y la conveniencia de una mayor inmediación de la autoridad sancionadora respecto de los hechos sancionados". Como bien explica Blanca Lozano Cutanda, la despenalización de ciertas conductas y la atribución de competencias sancionadoras a la Administración pública ha ido de la mano del reconocimiento de las garantías en el procedimiento administrativo sancionador. BLANCA LozANO CuTANDA, "Panorámica general de la potestad sancionadora de la Administración en Europa: 'despenalización' y garantía", Revista de Administración Pública, n. ${ }^{\circ}$ 121, Madrid: Centro de Estudios Políticos y Constitucionales, 1990, pp. 393 y ss.

$13 \mathrm{Al}$ respecto, por mencionar alguna de las diferencias importantes a las que hemos aludido en otro lugar, al explicar la diferencia entre los llamados procedimientos trilaterales y los procedimientos sancionadores con un denunciante interesado, en el procedimiento administrativo sancionador el funcionario es imparcial respecto del administrado, pero la Administración pública es la encargada de sancionar las conductas que afecten a ciertos bienes jurídicos, que se le ha encargado proteger, lo cual justifica justamente la atribución de potestad sancionadora. Si bien puede haber una diferencia entre el órgano instructor y el órgano decisor, ambos forman parte de la misma Administración pública, a diferencia de lo que ocurre en un proceso penal, en donde el fiscal -como titular de la acción penal-no forma parte del poder judicial, que debe tomar la decisión. Víctor Sebastián Baca Oneto, Protección al consumidor, Lima: INDECOPI, 2011, pp. 57 y ss. 
una conducta considerada punible. En consecuencia, dicha conducta debe reunir una serie de características que justifiquen la imposición de un castigo. Así, en primer lugar, debe existir una conducta, ya sea por acción o por omisión ${ }^{14}$, la cual debe ser atribuible al sujeto a quien se imputa, quien además debe poder ser pasible de un castigo. Asímismo, dicha conducta debe afectar injustificadamente a un bien jurídico, considerado valioso por el ordenamiento jurídico. Igualmente, dado que la consecuencia es un castigo, la conducta debe ser reprochable ${ }^{15}$, lo que excluye la atribución objetiva de responsabilidad y exige al dolo, o al menos negligencia, pues de otro modo no se podría castigar a quien lo hizo todo bien. Finalmente, el sujeto sobre el cual va a recaer el castigo ha de poder ser merecedor de un reproche y la sanción debe ser proporcionada a la conducta realizada. En consecuencia, solo una acción típica, antijurídica y culpable (que no es otra cosa que la definición de infracción o de delito) justifica la imposición de una sanción ${ }^{16}$.

A lo largo de las páginas siguientes se analizará con algo más de detalle la exigencia de culpabilidad, aun cuando es preciso hacer algunas aclaraciones previas sobre el alcance de este trabajo. Si bien normalmente se le vincula a la exigencia de dolo o culpa para poder sancionar, esto no es más que parte del contenido del principio de culpabilidad (de modo que la conducta pueda ser objeto de un juicio de reproche), que adicionalmente también incluye los principios de personalidad de las penas, imputación por el hecho y reprochabilidad subjetiva o culpabilidad en sentido estricto ${ }^{17}$.

En este trabajo nos referiremos a estos cuatro principios, englobados a su vez en un general principio de culpabilidad, para luego analizar con algo más de detalle algunos de los temas que puedan ser más discutibles, como los supuestos de infracciones formales de pura inobservancia y la responsabilidad de las personas jurídicas. El objetivo que nos proponemos es explicar la forma en que dichos principios se aplican, especialmente en los supuestos más controvertidos, tomando como referencia al derecho peruano, pese a que nuestro análisis y conclusiones pueden trascender de este ordenamiento y tener alcance

14 Como bien se ha indicado, no es posible confundir la voluntariedad de la conducta, necesaria para que haya acción u omisión, con la culpabilidad, como exigencia de un juicio de reproche. Manuel Rebollo Puig, Potestad sancionadora, alimentación y salud pública, Madrid: INAP, 1989, p. 618. Véase al respecto STS de 27 de mayo de 1999, artículo. 4504.

15 Como bien indica María José Gallardo Castillo, "no basta el puro desvalor del resultado ni de la lesión objetiva del bien jurídico protegido, sino que se requiere el desvalor de la acción por la consecuencia de la comisión, ya dolosa, ya culposa de la conducta que ha debido ser realizada con plena conciencia de su antijuridicidad y de imputabilidad y sin que concurran circunstancias que al sujeto le exoneren de la misma". María José Gallardo Castillo, Los principios de la potestad sancionadora administrativa. Teoría y práctica, Madrid: Iustel, 2008, p. 154.

16 Manuel Gómez Tomillo e Iñigo Sanz Rubiales, óp. cit., p. 101; Manuel Rebollo Puig, "El contenido de las sanciones", óp. cit., p. 154.

17 Manuel Gómez Tomillo e Iñigo Sanz Rubiales, óp. cit., pp. 356 y ss. 
general, razón por la cual hemos recurrido no solo a la doctrina y jurisprudencia peruana sino también a la de otros países de nuestro entorno. No obstante, no pretendemos agotar todos los temas posibles. Así, por ejemplo, si bien en algunos casos resulta imposible no mencionarlos, no se analizan con detalle los supuestos de exclusión de la culpabilidad, que, como el error, han sido objeto de una reciente modificación legislativa en el caso peruano ${ }^{18}$.

\section{EL CONTENIDO DEL PRINCIPIO DE CULPABILIDAD}

\subsection{El PRINCIPIO DE PERSONALIDAD DE LAS PENAS}

El principio de personalidad de las penas implica que únicamente pueden ser sancionados quienes hubieran realizado la conducta infractora, dado que en derecho administrativo sancionador es imposible disociar autoría y responsabilidad $^{19}$. Por tanto, este principio excluiría la posibilidad de que se impongan sanciones subsidiarias, en las cuales un sujeto (el responsable) responda por

18 Uno de los supuestos más interesantes, que no ha sido expresamente previsto en nuestra legislación, es el caso del estado de necesidad, que para algunos autores excluiría la reprochabilidad subjetiva, porque al sujeto no le es exigible una conducta diferente. MARía José Gallardo Castillo, óp. cit., pp. 168 y ss. Para otros, más bien excluiría la antijuridicidad de la conducta. Manuel Gómez Tomillo e Iñigo Sanz Rubiales, óp. cit., pp. 423 y ss. No obstante, cualquiera que sea el fundamento, nos parece claro que no corresponde sancionar si existe un estado de necesidad justificante.

19 En este sentido, entre otros, Ángeles de Palma del Teso, "Principio de culpabilidad. Causas de exclusión y atenuación de la responsabilidad", Diccionario de Sanciones administrativas, Madrid: Iustel, 2010, p. 711. Como bien explica esta autora, uno de los supuestos en que adquiere relevancia este principio es para justificar la extinción de la responsabilidad en caso de muerte. Si bien no es el momento de profundizar en este tema, consideramos que si una sanción pecuniaria ha sido impuesta mediante un acto que ha agotado la vía administrativa y el sancionado muere durante la tramitación del contencioso administrativo, dado que uno de los criterios para determinar la sanción es el beneficio ilícito y no se ha regulado el "comiso" de dicho beneficio, debe considerarse que el monto adeudado por el infractor se ha incorporado a su patrimonio, por lo que constituye un pasivo, que debe ser restado del activo del causante. Con más razón se debe aplicar el mismo criterio si la sanción ha quedado firme o ha sido confirmada con efectos de cosa juzgada en sede judicial. Esta afirmación no significa que los herederos "heredan la sanción", porque si esta supera al activo, pueden rechazar la herencia. Este criterio fue asumido en Chile en el célebre "caso Chispas", cuando se ordenó a los herederos de Luis Fernando Mackenna pagar la multa que le había sido impuesta en vida, pese a que había muerto durante la tramitación del proceso judicial. En el caso de las personas jurídicas, la situación es bastante más compleja, dado el carácter voluntario que tiene la extinción de éstas. Véase sobre este tema, Víctor Sebastián Baca Oneto y Eduardo Ortega Sarco, "La extinción de la responsabilidad sancionadora en los supuestos de fusiones, aplicada a la contratación pública", Derecho y Sociedad, n. ${ }^{\circ}$ 45, Lima: Asociación Civil Derecho y Sociedad de la Pontificia Universidad Católica del Perú, 2015, pp. 295 y ss. 
otro (el infractor $)^{20}$. Solo cabe imponer una sanción si se entiende que el "responsable" es coautor de la infracción o se considera que ha cometido a su vez otra infracción, tipificada como tal por el ordenamiento jurídico ${ }^{21}$. Aunque se trate esencialmente de obligaciones pecuniarias, no puede buscarse una explicación en las reglas de la responsabilidad civil, porque se trata de la imposición de una sanción. En este sentido, es interesante el supuesto contemplado en el artículo 289 del Decreto Supremo 016-2009-MTC, TUO del Reglamento Nacional de Tránsito ${ }^{22}$, de acuerdo al cual:

El conductor de un vehículo es responsable administrativamente de las infracciones de tránsito vinculadas a su propia conducta durante la circulación.

Cuando no se llegue a identificar al conductor infractor, se presume la responsabilidad administrativa del propietario del vehículo, salvo que acredite de manera indubitable que lo había enajenado, o no estaba bajo su tenencia o posesión, denunciando en ese supuesto al comprador, tenedor o poseedor como responsable.

En el servicio de transporte, se considerará al conductor como el tenedor del vehículo. En este caso, corresponde al propietario o legítimo poseedor del vehículo probar indubitablemente quién era el responsable de la conducción del mismo, al momento de cometerse la infracción, para que no le sea aplicado el supuesto previsto en el párrafo anterior.

Es decir, si no es posible determinar quién fue el autor de la infracción, responde el propietario del vehículo, salvo que pueda identificar al tenedor o poseedor. Por tanto, es interesante determinar si el propietario debe cumplir

20 En contra, Alejandro Nieto propone la distinción entre autor y responsable, en tanto el primero sería quien realizaría el hecho y el segundo a quien jurídicamente se le imputaría. Alejandro Nieto, óp. cit., pp. 425 y ss.

21 Uno de los supuestos en donde se ponía en tela de juicio la aplicación de este principio era en materia de contratos públicos, al extenderse la sanción como impedimento a las personas jurídicas que tuvieran titulares o representes comunes con las que hubieran sido inhabilitadas. Afortunadamente, esta regulación ha sido modificada, eliminándose este supuesto. Al respecto, muy crítico con la normativa precedente, véase EDUARDO OrTEGA SARCO, "Adiós al principio de culpabilidad, en especial a la personalidad de las penas". Disponible en línea http://www.ius360.com/publico/administrativo/adios-al-principiode-culpabilidad-en-especial-a-la-personalidad-de-las-penas/ [consultado el 8 de agosto de 2018].

22 Las normas sobre tráfico son un supuesto clásico para el análisis del principio de personalidad de las penas, dado que existe numerosos casos en los cuales se responde por la omisión de un deber de garante (si no se hizo todo lo posible por impedir la conducta de otro). En estos casos, se invierte la carga de la prueba, debiendo el imputado probar que cumplió con dicho deber o que, en todo caso, su conducta fue diligente. Sobre este tema, Tomás Cano Campos, "La culpabilidad y los sujetos responsables en las infracciones de tráfico", Documentación Administrativa, n. ${ }^{\circ} 284-285$, Madrid: INAP, 2009, pp. 94 y ss. 
con la sanción como mero "responsable" o como "presunto autor". Al permitírsele excluir su responsabilidad denunciando al verdadero infractor, parece evidente que nuestra norma está presumiendo su autoría y, a partir de ella, su responsabilidad. Es decir, el propietario responde como autor (presunto) de la infracción, no como responsable de la conducta de otro ${ }^{23}$. Así se justifica, por ejemplo, que no solo se le impongan penas pecuniarias, sino incluso las no pecuniarias, como la pérdida de los puntos de la licencia de conducir.

Más complicado es el caso del propietario que puede probar que no conducía el vehículo, pero no sabe (ni puede saber) quién lo conducía (quién era su poseedor o su tenedor), de modo que no puede denunciar a nadie. Sería el caso de una persona que ha salido del país, y, mientras tanto, se comete una infracción con su vehículo, detectada por medios electrónicos. ¿Puede probar que no es el autor? Sí, con su registro migratorio. ¿Responde en ese caso ante la Administración, si no puede mostrar quién tenía su vehículo? Si lo hace, sería a título de "responsable", no de autor (pues ha desvirtuado la presunción). ¿Es admisible en nuestro derecho? Dependerá del reconocimiento que se haga del principio de culpabilidad en derecho administrativo sancionador, pues implica responder por el acto de otro. No debe olvidarse que la "culpabilidad" no solo significa la exigencia de dolo o culpa, sino también el carácter personal de las infracciones, reconocido por el artículo 246.8 LPAG: la responsabilidad debe recaer en quien realiza la conducta constitutiva de infracción ${ }^{24}$. Por tanto, si quiere sancionarse al propietario del vehículo, sería por la omisión de un deber de cuidado de su vehículo (una especie de deber de garante), cuya tipificación en el reglamento citado es al menos dudosa ${ }^{25}$.

24 Con especial insistencia sobre este punto, Manuel Rebollo PuiG, "Los principios de responsabilidad, personalidad y culpabilidad en la determinación de los responsables de las infracciones", en Régimen jurídico básico de las Administraciones públicas. Libro bomenaje al profesor Luis Cosculluela, Madrid: Iustel, 2015, pp. 846 y ss. Como afirma este autor, el principio de personalidad de las penas, el de legalidad y el de exigencia de dolo o culpa pueden admitir adaptaciones al ser aplicados en el derecho administrativo sancionador, pero de ninguna manera admiten excepciones (pp. 853-854). Cabe mencionar, por ejemplo, la posición de José Cid Moliné, quien defiende una tesis "diferenciadora" entre las garantías que deben aplicarse en derecho administrativo sancionador y derecho penal, a partir de la diferente gravedad de las sanciones. Sin embargo, también para este autor los principios de legalidad material, culpabilidad, proporcionalidad y humanidad se aplican en ambos ámbitos, en tanto son funcionales para la finalidad preventiva. José Cid Moliné, "Garantías y sanciones (Argumentos contra la tesis de la identidad de garantías entre las sanciones punitivas)", Revista de Administración Pública, n. ${ }^{\circ}$ 140, Madrid: Centro de Estudios Políticos y Constitucionales, 1996, pp. 147 y ss. Las diferencias radicarían en los que llama principios de ofensividad y jurisdiccionalidad, de modo que en derecho administrativo sancionador serían punibles acciones que no produzcan lesiones a bienes jurídicos y el nivel de exigencia probatoria debería ser menor al penal.

25 En derecho español, se solía afirmar que el supuesto contemplado en la Ley 30/1992 de "subsidiariedad" en realidad no era tal, porque permitía imponer una sanción si se vulneraba 
Por otro lado, el artículo 249.2 LPAG permite expresamente que se impongan sanciones de las cuales se responde en forma solidaria, siempre y cuando se trate del cumplimiento de obligaciones previstas en una disposición legal que les correspondan a varias personas conjuntamente. Si bien se trata de un supuesto límite (dado que se obligaría a responder íntegramente por las consecuencias de la infracción a uno de sus autores), la forma en que esta norma está redactada (que corresponde casi exactamente al texto español de la Ley 30/1992) permite justificarla ${ }^{26}$. Así, de acuerdo a la norma citada, la responsabilidad solidaria es exigible "cuando el cumplimiento de las obligaciones previstas en una disposición legal corresponda a varias personas conjuntamente". No se trata de una obligación parciaria (donde cada quien debe cumplir con algo), ni de una solidaria tal como las define nuestro Código Civil (cualquiera puede con el íntegro de la obligación), sino de una verdadera obligación mancomunada, cuyo cumplimiento le corresponde todos los obligados en común ${ }^{27}$.

Por tanto, se trata de una obligación que debían cumplir todos en conjunto, por lo que podría encontrar justificación que todos sean responsables por el total de la sanción, en tanto responden por su propio incumplimiento ${ }^{28}$. No

un deber de garante. Ángeles de Palma del Teso, "Principio de culpabilidad. Definición...", óp. cit., p. 716. Es decir, se sancionaba a alguien por su propio incumplimiento. Sin embargo, la Ley 40/2015 del Régimen Jurídico del Sector Público introduce un supuesto nuevo, al establecer que las leyes "podrán prever los supuestos en que determinadas personas responderán del pago de las sanciones pecuniarias impuestas a quienes de ellas dependan o estén vinculadas". Se trataría, por tanto, de un supuesto de responsabilidad subsidiaria que, si no se vincula al incumplimiento de un deber de garante, resulta muy cuestionable. Manuel Rebollo Puig sostiene que estaríamos ante una subsidiariedad en el pago, que también tiene carácter sancionador, por lo que dicha responsabilidad debe "basarse en una conducta ilícita propia y siquiera culposa del responsable solidario o subsidiario". Véase Manuel Rebollo Puig, "Los principios de la potestad sancionadora en la Ley española del Régimen Jurídico del Sector Público", en Derecho administrativo sancionador, Lima: Instituto Pacífico, 2017, pp. 100-103, para criticar a continuación los mecanismos procedimentales existentes para que este se defienda.

26 En contra, Alejandro Huergo Lora, Las sanciones administrativas, Madrid: Iustel, 2007, pp. 395 y ss., para quien la solidaridad es abiertamente contraria al principio de culpabilidad, al igual que la subsidiariedad.

27 Véase Ángeles de Palma del Teso, "Principio de culpabilidad. Definición...", óp. cit., pp. 713 y ss. Sin embargo, como bien se explica, la atribución de responsabilidad solidaria no implica negar que cada uno de los sujetos a los que se les imponga el castigo haya cometido la acción punible y que, además, haya actuado con dolo o culpa.

28 Sobre la necesidad de que exista una infracción atribuible a cada uno de los responsables, véase, por ejemplo, María José Gallardo CASTillo, óp. cit., pp. 202 y ss. En palabras de Manuel Gómez Tomillo e Iñigo Sanz Rubiales, los supuestos de solidaridad tendrían que ser abordados como casos de coautoría (aun cuando en algún caso extraordinario podrían responder unos a título de autores y otros como partícipes, caso en el que deberían tener una responsabilidad diferente). Sin embargo, incluso bajo este supuesto, debido a que el monto de la sanción puede tener que ser pagado íntegramente de modo aleatorio por cualquiera de los autores (como sucedería, por ejemplo, en caso de muerte de uno de 
obstante, lo cierto es que la regla general es la individualización de las responsabilidades, al menos cuando sea posible, especialmente si la sanción es pecuniaria (como lo establece, por ejemplo, el artículo 28.3 de la Ley 40/2015 española). $\mathrm{Al}$ respecto, encontramos una muestra de este tipo de responsabilidad en la legislación sobre contratos con el Estado: en el caso de una oferta presentada en consorcio se permite la individualización de responsabilidades, porque cada quien puede ser responsable de sus propios documentos (por ejemplo). Sin embargo, si una vez suscrito el contrato se produce una infracción imputable al contratista (que son ambos consorciados), la sanción se impondrá a todos los integrantes del consorcio.

\subsection{El PRINCIPIO DE IMPUTACIÓN POR EL HECHO}

Por su parte, el principio de imputación por el hecho exige que, para imponer una sanción, exista una acción (o una omisión), con la peculiaridad frente al derecho penal que en derecho administrativo sancionador no se regula la tentativa. Por tanto, si no hay acción, no puede haber una sanción. Este principio ha sido recogido en nuestra legislación a través del principio de causalidad, y adquiere especial importante en dos casos: a) la regulación de la reincidencia ; y b) los supuestos en que junto a una sanción se impone como consecuencia adicional la pérdida de puntos (como sucede con el carnet de conducir).

En primer lugar, respecto de la reincidencia, debemos indicar que la normativa administrativa no es ajena a su configuración. En el caso del derecho penal, es interesante constatar cómo la legislación vigente la reconoce ${ }^{29}$, contradiciendo lo que sigue diciendo la exposición de motivos del Código Penal, de acuerdo a la cual:

Resulta imperativo connotar las razones principales por las que la Comisión Revisora decidió proscribir del Proyecto de Código Penal, los institutos penales de la reincidencia y la habitualidad. Hoy no resulta válido, en verdad, conservar en nuestro ordenamiento jurídico estas formas aberrantes de castigar que sustentan su severidad en el modo de vida de un individuo (derecho penal de autor). La Comisión Revisora estima que carece de lógica, humanidad y sentido jurídico, el incremento sustantivo de la pena correspondiente a un nuevo delito, vía la reincidencia o habitualidad, sin otro fundamento que la existencia

ellos), dichos autores critican la admisión de la responsabilidad solidaria, porque afectan a los principios de personalidad de las sanciones, proporcionalidad e igualdad. MANUEL Gómez Tomillo e IÑigo Sanz Rubiales, óp. cit., pp. 576 y ss.

29 De acuerdo a la LPAG, la reincidencia es un factor de graduación (no un agravante), siempre que a) se cometa la misma infracción, b) en un plazo de un año, y c) desde que la primera sanción hubiera quedado firme. Se recoge, por tanto, la reincidencia específica y no es suficiente el agotamiento de la vía administrativa para apreciarla, sino que se exige la firmeza del acto que impuso la primera sanción. 
de una o varias condenas precedentes, por lo demás, debidamente ejecutadas. Dentro de este razonamiento, castigar a una persona tomando en cuenta sus delitos anteriores, cuyas consecuencias penales ya ha satisfecho, conlleva una violación del principio bis non in idem (nadie puede ser juzgado dos veces por un mismo delito), el mismo que se encuentra consagrado en el artículo 233 inc. 11 de la Carta Política. La experiencia ha demostrado que la drasticidad de las penas impuestas en nombre de la reincidencia y habitualidad, no han servido para atemorizar, de conformidad con criterios de prevención general, todo lo cual ha llevado a la Comisión Revisora a no incluir en el documento proyectado este rezago de los viejos tiempos del derecho de castigar y que el positivismo peligrosista auspició con el fin de recomendar la aplicación de medidas eliminatorias y de segregación social.

En realidad, el empleo de la reincidencia como factor de graduación no afecta el principio de non bis in idem ni el principio de imputación por el hecho, siempre y cuando lo que se castigue sea la realización de un nuevo hecho infractor (en este sentido, la STCE 155/1991, del 4 de julio, referida a la reincidencia como agravante del tipo penal), pero sí quedaría proscrito que se sancione como falta más grave la repetición de varias faltas de menor gravedad, debidamente sancionadas, en un periodo determinado. Debe diferenciarse que una situación será el utilizar los hechos anteriores como fundamento para imponer una sanción más severa por una conducta ilícita posterior, lo que estaría admitido; y otra inadmisible, el tipificar como infracción autónoma la mera acumulación de infracciones previas.

En este segundo caso no existiría un hecho nuevo, por lo que se castigarían conductas por las que el infractor ya ha sido sancionado y el fundamento de la sanción en todo caso sería el mismo, por lo que una norma que tuviera tal redacción violaría la prohibición de bis in idem. En este sentido, resulta cuando menos cuestionable la regulación establecida por la Ley 30225, Ley de Contrataciones del Estado peruana, según la cual uno de los supuestos que permitiría la imposición de una inhabilitación definitiva es la acumulación de más de dos sanciones de inhabilitación por diversas infracciones (debidamente castigadas) por un periodo total mayor de 36 meses en los últimos cuatro años. En este sentido, la sanción de inhabilitación definitiva se impondría sin hecho infractor alguno.

Por otro lado, están los supuestos en donde la comisión de una infracción trae como consecuencia la imposición de una sanción y la sustracción (o acumulación) de una serie de puntos, en virtud de los cuales puede perderse un título habilitante. En este caso, si se entiende que la pérdida del título habilitante constituye una sanción (como probablemente sea correcto), estaríamos nuevamente en un supuesto en el cual existiría una sanción sin hecho infractor. Por esta razón, quienes defienden estas técnicas niegan que se trate de verdaderas sanciones y las igualan a las revocaciones por desaparición de 
condiciones subjetivas (las medidas rescisorias o la revocación sanción, a la que nos hemos referido en otro lugar ${ }^{30}$ ).

\subsection{El PRINCIPIO DE EXIGENCIA DE DOLO O CULPA O DE TIPICIDAD SUBJETIVA}

Seguramente el aspecto más controvertido del principio de culpabilidad ha sido (y es) el reconocimiento de la exigencia de dolo o cuando menos culpa para imponer una sanción ${ }^{31}$. Si bien históricamente se ha defendido la posibilidad de imponer sanciones de modo objetivo, lo cierto es que el progresivo acercamiento del derecho administrativo sancionador a los principios y garantías del ius puniendi único del Estado han ocasionado que este principio goce de pleno reconocimiento, a nivel doctrinal y jurisprudencial ${ }^{32}$, aunque nuestra

30 Víctor Sebastián Baca Oneto, "La naturaleza revocatoria y los límites de la extinción...", óp. cit. Uno de los supuestos en donde adquiere relevancia la definición de una medida como sanción o no, a efectos de determinar si se respeta el principio de imputación por el hecho, es el caso de la retirada del carnet por puntos. Si es una sanción, se trataría de un castigo sin un hecho infractor, razón por la cual se ha sostenido que se trata de una revocación por incumplimiento de una condición subjetiva (al no tener puntos suficientes para conservar el carnet). Al respecto, véase TOMÁs CANO CAMPOS, "¿Es una sanción...", óp. cit., pp. 79 y ss. Este autor, para quien la retirada del carnet tiene carácter sancionador, afirma sin embargo que "la revocación del permiso por la pérdida de todos los puntos no es el castigo o retribución por una nueva infracción, sino la efectividad o materialización de las sanciones previamente impuestas por la comisión de las infracciones previamente cometidas" (p. 112). Se trataría de una sanción, adicional a la multa, "que solo opera de manera acumulada o por agregación de otras infracciones ulteriores, quedando por ello inicialmente en suspenso" (p. 113).

31 Así, por ejemplo, en uno de los primeros trabajos publicados en nuestro país en donde se defiende la unidad del ius puniendi estatal y la aplicación de una serie de principios al derecho administrativo sancionador, no tiene ninguna referencia al principio de culpabilidad. Jorge Danós Ordóñez, "Notas sobre la potestad sancionadora de la Administración", Ius et Veritas, n. ${ }^{\circ}$ 10, Lima: Asociación Civil Derecho y Sociedad de la Pontificia Universidad Católica del Perú, 1994, pp. 159 y ss. Más adelante, al publicarse la LPAG original, en el año 2001, se omitió la referencia a este principio, sin que esto fuera materia de comentario alguno en aquel momento. Al respecto, véase, por ejemplo, Roberto Pereira Chumbe, "La potestad sancionadora de la Administración y el procedimiento administrativo sancionador en la Ley 27444", en Comentarios a Ley del Procedimiento administrativo general, Lima: ARA, 2001, pp. 279 y ss.

32 Sobre este tema, es esencial la referencia a Ángeles de PAlma del TeSo, El principio de culpabilidad..., óp. cit., así como a los trabajos posteriores de la misma autora, "La culpabilidad", Justicia Administrativa, número extraordinario, Valladolid: Lex Nova, 2001, pp. 29 y ss.; y "Principio de culpabilidad. Definición...", óp. cit., pp. 702 y 722. Si bien no es el primero sobre la materia, es relevante la referencia también al trabajo de MAnuel Rebollo Puic ( $P_{0}$ testad sancionadora..., óp. cit., pp. 618 y ss.), donde ya se defiende la aplicación del principio de culpabilidad en el derecho administrativo sancionador. Más recientemente, resulta fundamental el trabajo de Manuel Gómez Tomillo e Iñigo SAnZ Rubiales, óp. cit., pp. 355 y ss. y pp. 431 y ss. En contra, es obligada la referencia a AlejandRo NieTo, óp. cit., pp. 145 y ss., y 323 y ss. Para este autor, las infracciones de inobservancia, en casos de conductas 
LPAG introduce una modulación, la cual puede resultar de discutible constitucionalidad. En este sentido, la prohibición de una responsabilidad objetiva ha sido puesta de manifiesto por diversas sentencias del Tribunal Constitucional, dentro de las cuales cabe citar especialmente la Sentencia del 3 de septiembre de 2010, recaída en el Expediente 1873-2009-PA/TC, en la cual expresamente se indica que el principio de culpabilidad implica la exclusión de cualquier responsabilidad objetiva.

Como hemos dicho, cuando la Administración ejerce una potestad sancionadora, impone un castigo, lo que solo se justifica cuando el sujeto pudo haber actuado de otro modo, haciéndose por tanto merecedor a un juicio de reproche, sin el cual una sanción no tiene sentido alguno ${ }^{33}$. A diferencia de la responsabilidad civil, que únicamente busca establecer quién debe asumir el daño y no conlleva un castigo, la responsabilidad en materia punitiva implica imponer una medida con un fin aflictivo, la cual tiene que estar correctamente justificada y exige cuando menos un comportamiento negligente por parte del autor. A diferencia del derecho penal, donde la regla general es que resulta exigible el dolo para poder sancionar, en derecho administrativo resulta suficiente la culpa, pero en todo caso esta resultaría indispensable. Esta exigencia de un actuar negligente constituye un elemento del tipo infractor, que no sería otro que la tipicidad subjetiva o el juicio de reproche objetivo, en tanto está dirigido a la conducta y no al autor (que sería más bien el juicio de reproche subjetivo, al que nos referimos más adelante).

En este caso, existirá culpa o negligencia cuando se produzca el resultado no querido por la norma o se realice la conducta generadora del riesgo, pese a que el sujeto pudo y debió evitarlo, observando y cumpliendo una norma que imponía un deber de cuidado ${ }^{34}$. En consecuencia, una conducta será negligente cuando no hubiera sido posible actuar de modo diferente, mientras que no lo será si el resultado o riesgo prohibido se hubiera producido de cualquier modo.

sancionables por peligro abstracto, constituyen supuestos donde no es necesario acudir a la culpabilidad, ni siquiera definida como imprudencia levísima.

33 No compartimos, por tanto, la afirmación de Palma del Teso, para quien el carácter exclusivamente preventivo que le atribuye al derecho administrativo sancionador implica no solo que la culpabilidad no requiere un análisis psicológico del autor y está desprovista de cualquier componente ético o moral, sino que la idea del reproche le resultaría aneja. Es necesario un juicio de reproche, aun cuando este se construya de forma diferente a lo que sucede en derecho penal (especialmente en el caso de las personas jurídicas). Como se ha indicado más arriba (nota 6), este reproche tiene carácter jurídico, no ético o moral. Ángeles de Palma del Teso, "Principio de culpabilidad. Definición...", óp. cit., pp. 705-706.

34 Véase, María José Gallardo Castillo, óp. cit., p. 163. De acuerdo a esta autora, existirá culpa cuando se vulnere un deber objetivo de cuidado $y$, además, exista una inobservancia del deber de cuidado, subjetivamente considerado, para lo cual deben incorporarse dos requisitos alternativos, de modo que al menos uno debe estar presente: a) que el peligro sea previsible para el individuo en particular; o b) que al sujeto le sea normativamente exigible su conocimiento (pp. 165 y ss.). 
En estos casos adquiere una gran importancia determinar los estándares de diligencia, en función de los cuales corresponderá enjuiciar la conducta, a efectos de establecer si constituye una vulneración de un deber de cuidado.

Además, dada esta definición de negligencia, quedaría claro que, en los supuestos de error invencible, esta quedaría excluida. Como es sabido, es posible diferenciar entre error de tipo (hay una equivocación respecto de la materialización de alguno de los elementos del tipo) y error de prohibición (la equivocación se refiere a la prohibición de la conducta, que se cree permitida). Más allá de que sea posible discutir si ambos supuestos afectan a la culpabilidad o inciden sobre algún otro elemento de la infracción ${ }^{35}$, lo que nos parece claro es que únicamente el error invencible debería justificar una exoneración de responsabilidad, de modo que el error vencible no sería otra cosa que un supuesto de acción negligente, lo que es suficiente en derecho administrativo para imponer un castigo. Sin embargo, el texto de la LPAG no diferencia entre ambos tipos de error, por lo que es importante interpretarlo correctamente, reservando la eficacia eximente para el error invencible ${ }^{36}$.

El texto original de la LPAG no establecía nada respecto de este principio, limitándose a indicar que la intencionalidad constituía un factor de graduación ${ }^{37}$. En realidad, esta norma únicamente establecía que la intencionalidad, la cual se relaciona con el dolo, podía agravar la responsabilidad, pero nada decía respecto de la culpa que debería ser un elemento del tipo. Sin embargo, la jurisprudencia del Tribunal Constitucional peruano fue explícita respecto del reconocimiento del principio de culpabilidad, en el sentido de exigencia de cuando menos negligencia y la proscripción de la responsabilidad objetiva ${ }^{38}$.

Así, por ejemplo, para María José Gallardo Castillo, el error de tipo implica una atipicidad de la conducta, mientras que el error de prohibición sí incidiría sobre la culpabilidad, al no existir conciencia de la antijuridicidad. María José Gallardo Castillo, óp. cit., pp. 172 y ss. En el mismo sentido, Tomás Cano Campos, "La culpabilidad y los sujetos responsables...", óp. cit., p. 112

36 Estrechamente relacionada al error como eximente de responsabilidad estaría la referencia que algunos autores hacen al principio de confianza legítima, que sería una causa de exclusión de la culpabilidad, cuando el Estado haya generado la confianza de que la conducta no sería sancionable o incluso ha obligado a su realización. Al respecto, véase JOSÉ CARLOS LAGUNA DE PAZ, "Culpabilidad y responsabilidad personal en las sanciones administrativas en materia de defensa de la competencia en el Derecho europeo y español", Revista de Derecho de la Universidad de Piura n ${ }^{\circ}$ 18, Piura: Universidad de Piura, 2017, pp. 163 y ss.

37 Como bien lo explicó en su momento Manuel Gómez Tomillo, "la intencionalidad a la que esta norma aludía era al dolo, de modo que no se decía nada respecto de la negligencia. Manuel Gómez Tomillo, "Derecho administrativo sancionador y derecho penal. Análisis del derecho positivo peruano. Especial consideración de los principios de legalidad, culpabilidad y oportunidad", Revista de Derecho de la Universidad de Piura, n. ${ }^{\circ}$ 4, Piura: Universidad de Piura, 2003, pp. 51 y ss.

38 En palabras de Juan Carlos Morón Urbina, "a falta de norma, en nuestro derecho ha sido introducido jurisprudencialmente por el Tribunal Constitucional como una exigencia para ejercer legítimamente la potestad sancionadora". Juan Carlos Morón Urbina, "Los 
Así, por ejemplo, puede citarse como ejemplo la ya mencionada Sentencia del 23 de septiembre de 2010 (Expediente 01873-2009-AA/TC), que expresamente alude a una proscripción de la responsabilidad objetiva en el derecho administrativo sancionador. No obstante, pese a esto, no solamente algunas normas (especialmente en lo que se relaciona a sanciones medioambientales), sino también las Administraciones públicas afirmaban que la responsabilidad era objetiva.

El Decreto Legislativo 1272, al modificar a la LPAG, ha pretendido cerrar esta discusión, incluyendo dentro de los principios del derecho administrativo sancionador el de culpabilidad, según el cual la responsabilidad administrativa es subjetiva, incluyendo, además, el error como uno de los eximentes de responsabilidad. Este segundo cambio, como se ha explicado líneas arriba, probablemente peca por exceso al no restringir expresamente el error a los supuestos en que resulta invencible ${ }^{39}$, mientras que el primero peca por defecto, dado que establece una excepción, en virtud de la cual es posible sancionar sin necesidad de culpa: la norma agrega que la responsabilidad puede ser objetiva si una ley o un decreto legislativo así lo establecen ${ }^{40}$.

principios delimitadores de la potestad sancionadora de la Administración pública en la ley peruana", Revista Advocatus, n. ${ }^{\circ}$ 13, Lima: Revista de los Alumnos de la Universidad de Lima, 2005, p. 248.

39 De acuerdo a la ley peruana, es un eximente de responsabilidad "el error inducido por la Administración o por disposición administrativa confusa o ilegal". El primer supuesto es uno de aquellos en los que tradicionalmente se admite la existencia de error. Sin embargo, el segundo puede ser más discutible, dado que debe ser necesario acreditar el carácter invencible del error y las disposiciones confusas podrían no ser suficientes para lograrlo. Adicionalmente, si una disposición administrativa es ilegal, no puede servir para imponer una sanción, porque en ese caso dicha decisión resultaría ilegal. Finalmente, es interesante un supuesto, no expresamente regulado en la LPAG, en donde la Administración induciría al error sobre la legalidad de la conducta a partir del criterio seguido en algunos precedentes, que luego es modificado por la entidad. En este caso, más que ante un supuesto de error, estaríamos ante un supuesto en el cual debe ser aplicado el principio de irretroactividad, como hemos explicado en otro lugar. Víctor Sebastí́n Baca Oneto, "La retroactividad favorable en derecho administrativo sancionador", Themis. Revista de Derecho, n. ${ }^{\circ} 69$, Lima: Pontificia Universidad Católica del Perú, 2016, p. 36.

40 En su momento, había defendido la posibilidad de una aplicación excepcional de la responsabilidad objetiva, si hubiera base legal expresa, Roberto Shimabukuru MaKiKado, "Reflexiones sobre el principio de culpabilidad y la responsabilidad administrativa objetiva", Congreso Internacional de Derecho administrativo. Derecho administrativo en el siglo XXI, vol. I, Lima: Editorial Adrus, 2013, p. 742. Por otro lado, llama la atención la posición de algunos autores que, luego de defender la aplicación del principio de culpabilidad y hacer una explicación histórica acerca de su reconocimiento por el Tribunal Constitucional, aceptan sin mayores críticas la redacción de la LPAG, que admite las excepciones a través de leyes. Es el caso, por ejemplo, de VerÓnICA Rojas MONTES, "La responsabilidad administrativa subjetiva de las personas jurídicas", Revista de Direito Econômico e Socioambiental . v 8, n. ${ }^{\circ} 2$, Curitiba: Pontifícia Universidade Católica do Paraná, 2017, p. 11 (nota a pie de página 9) ; y LuigGi SANTy CabreRA, "El principio de culpabilidad como responsabilidad subjetiva 
Así, aquellos ámbitos en los cuales las leyes establecían una responsabilidad objetiva, seguirá aplicándose una responsabilidad sin culpa, al igual que en el caso de aquellos en los cuales una norma así lo establezca luego de la entrada en vigencia de la LPAG (como, por ejemplo, la modificación de la Ley de Contrataciones del Estado, la cual resultaría aplicable a las infracciones cometidas luego de su entrada en vigencia, ya que antes no había norma que expresamente dijera que la responsabilidad era objetiva y debería aplicarse el criterio de la LPAG, como norma más favorable para todas las anteriores). Sin embargo, cuando el Tribunal Constitucional había proclamado que la responsabilidad en materia sancionadora no podía ser objetiva, no lo hacía porque la exigencia de dolo o culpa se desprendiera de una ley, sino porque se trata de una exigencia constitucional. Por tanto, nada habría cambiado respecto de la inconstitucionalidad de la responsabilidad objetiva: antes lo era cuando la Administración pretendía aplicarla, sin base legal, y ahora lo sigue siendo, cuando una ley pretende establecerla ${ }^{41}$.

No obstante, existen algunos casos en donde se ha pretendido utilizar la excepción prevista en la LPAG. Es el caso, por ejemplo, de la reciente modificación de la Ley 30225 realizada mediante el Decreto Legislativo 1341 ( 7 de enero de 2017), que expresamente alude al carácter objetivo de la responsabilidad por las infracciones (salvo que los tipos infractores admitan la posibilidad de justificación). En similar sentido, el Decreto Legislativo 1349 (7 de enero de 2017) ha establecido que, en los procedimientos sancionadores seguidos por la $\mathrm{Su}$ perintendencia de Banca, Seguros y AfP, la responsabilidad será subjetiva para las infracciones leves y objetiva para las graves y muy graves. Antes de la modificación de la LPAG, el artículo 18 de la Ley 29325, Ley del Sistema Nacional de Evaluación y Fiscalización Ambiental (4 de marzo de 2009), recogía un supuesto de responsabilidad objetiva, que no habría quedado derogado por la modificación de la LPAG, al establecer que "Los administrados son responsables objetivamente por el incumplimiento de obligaciones derivadas de los instrumentos de gestión ambiental, así como de la normas ambientales y de los mandatos o disposiciones emitidas por el OEFA".

Sin embargo, en muchas ocasiones las normas no son explícitas respecto del carácter objetivo de la infracción, resultando insuficientes, por tanto, para satisfacer los requisitos establecidos en la LPAG. Al respecto, tiene especial interés

en el derecho administrativo sancionador", Administración Pública \& Control, n. ${ }^{\circ} 44$, Lima: Editorial Gaceta Jurídica, 2017, pp. 74 y ss.

41 En el caso colombiano, sin embargo, se habrían admitido supuestos excepcionales en los cuales se aplicaría una responsabilidad objetiva. Al respecto, véase MARía LOURDES RAMírEZ Torrado, "Consideraciones de la Corte Constitucional acerca del principio de culpabilidad en el ámbito sancionador administrativo", Revista de Derecho. Universidad del Norte, n. ${ }^{\circ}$ 29, Barranquilla: Universidad del Norte, 2008, pp. 160 y ss. 
lo resuelto en la casación 13233-2014, del 17 de mayo de 2016 ${ }^{[42]}$, en relación a la existencia o no de responsabilidad objetiva en el Código Tributario, a partir de lo dispuesto por el artículo 165 de dicha norma, según el cual "la infracción será determinada en forma objetiva y sancionada administrativamente con penas pecuniarias". Así, de acuerdo a la citada sentencia, dicha disposición

está dirigida a la autoridad tributaria, a quién le atribuye e indica cómo debe determinar la infracción, esto es, determinarla en forma objetiva, mas no le atribuye definir ni restringir los supuestos o elementos del tipo infractor previstos en la ley, reafirmando que ello implica, que cuando la autoridad administrativa tributaria sancionadora, determine una infracción, debe hacerlo de manera objetiva, exigencia que tiene sustento en el principio de seguridad jurídica, reduciendo el grado de discrecionalidad administrativa en la aplicación del régimen sancionador ${ }^{43}$.

Por tanto, una norma como la contenida en el Código Tributario resulta insuficiente para justificar que la responsabilidad sea objetiva, lo cual resulta de gran importancia, ya que son numerosos los casos en donde una norma similar pretender ser empleada con tal fin. Así, por ejemplo, en el caso del OSINERGMIN se ha venido utilizando fundamento para reconocer una responsabilidad objetiva lo dispuesto por la Ley 27699, Ley de Fortalecimiento Institucional del Organismo Supervisor de la Inversión en Energía (del 16 de abril de 2002), "la infracción será determinada en forma objetiva y sancionada administrativamente, de acuerdo a la Escala de Multas y Sanciones del OSINERG". Aplicando el criterio mencionado, esta norma sería insuficiente para cumplir con el criterio introducido por la LPAG, por lo que no habría base legal para exigir una responsabilidad objetiva en este caso.

\subsection{EL PRINCIPIO DE CULPA EN SENTIDO ESTRICTO \\ O DE REPROCHABILIDAD SUBJETIVA}

$\mathrm{Al}$ igual que en derecho penal, solo podría ser sancionado un sujeto que esté en condiciones de recibir un castigo, con la salvedad de que el derecho administrativo no contempla las medidas de seguridad, que sí se establecen

42 Publicada en el Diario Oficial El Peruano, el 31 de marzo de 2017.

43 Cabe señalar que esta sentencia no indica que la responsabilidad sancionadora en materia tributaria no pueda ser objetiva, sino que esto dependerá de la forma en que haya sido tipificada la infracción. Al respecto, es preciso poner de relieve que en este ámbito se ha pretendido no aplicar el principio de culpabilidad, en tanto mediante Decreto Legislativo 1311 (30 de diciembre de 2016) se modificó expresamente el Código Tributario para indicar que son aplicables al régimen sancionador los principios que este establece (entre los cuales no está el principio de culpabilidad) y no los contemplados en la LPAG, a pesar de esta expresamente indica que sus disposiciones sobre procedimiento sancionador se aplican también a los procedimientos tributarios. 
en el ámbito penal. Por tanto, si un administrado pudiera probar que no es imputable, por alguna condición subjetiva que pueda ser probada, no podría ser sancionado. En relación a las personas jurídicas, este elemento adquiere especial importancia en la medida que, como veremos más adelante, el análisis respecto del déficit de organización es un análisis respecto de la culpa, y no respecto del principio de tipicidad subjetiva.

En relación a las personas naturales, el artículo 255.c LPAG ha introducido como una de las causales de extinción de la responsabilidad "La incapacidad mental debidamente comprobada por la autoridad competente, siempre que esta afecte la aptitud para entender la infracción". Si bien esta norma no se refiere expresamente a la capacidad de obrar, igualmente podría aplicarse a las infracciones cometidas por menores de edad: si estos carecen de aptitud para entender la comisión de una infracción, no podrían ser sancionados. Sin embargo, en ciertos casos -como puede suceder, por ejemplo, cuando se les reconoce expresamente la facultad de ejercer ciertos derechos y facultades, porque se les presume capacitados para hacerlo- un menor de edad podría ser sancionable ${ }^{44}$.

\section{SUPUESTOS CONTROVERTIDOS DE APLICACIÓN DEL PRINCIPIO DE CULPABILIDAD}

\subsection{EL PRINCIPIO DE CULPABILIDAD Y LAS INFRACCIONES DE MERO DESCONOCIMIENTO}

No obstante, hay dos supuestos en los cuales la existencia de una responsabilidad subjetiva ha sido puesta en tela de juicio. El primero es el caso de las infracciones de mera inobservancia y el segundo es el caso de la responsabilidad de las personas jurídicas. En relación al primer punto, algunos ordenamientos (como sucedía en el derecho el español ${ }^{45}$ ) reconocen algunas infracciones de

44 Véase, al respecto, Sebastián Martín Retortillo, óp. cit., pp. 45-46; Manuel Rebollo Puig, Potestad sancionadora..., óp. cit., pp. 645 y ss.; y María José Gallardo Castillo, óp. cit., p. 159. Por su parte, Tomás Cano Campos sostiene que en el caso de las infracciones de tráfico este criterio resulta difícil de aplicar, porque un menor de ocho años podría ser sancionado por no respetar un semáforo, pero uno de diecisiete años no podría serlo por conducir un vehículo. Por esta razón, propone fijar una edad mínima de quince años, que resulta tan arbitraria como cualquier otra, pero que a su criterio tiene justificación en derecho español. Tomás Cano Campos, "La culpabilidad y los sujetos...", óp. cit., pp. 107 y ss.

45 El texto vigente de la Ley $40 / 2015$ ha eliminado la referencia a las infracciones de mera inobservancia, y establece dentro del principio de responsabilidad que únicamente podrán ser sancionados quienes resulten responsables a título de dolo o culpa, lo que habría cerrado en España cualquier discusión sobre el carácter objetivo de la responsabilidad. No obstante, compartimos las críticas a esta norma que ha hecho TOMÁs CANO CAMPOS, "La potestad sancionadora de la Administración: una regulación fragmentaria, incompleta y perniciosa", Documentación Administrativa. Nueva Época, n. ${ }^{\circ}$ 2, Madrid: INAP, 2015. 
mera inobservancia, las cuales se configurarían con el mero desconocimiento de una norma, que generalmente impone una obligación de carácter formal. Se trata de infracciones en las cuales no se exige un resultado, sino que la mera conducta ya es suficiente para que se configure el supuesto infractor. Normalmente, se entiende que en estos casos únicamente es exigible una "culpa levísima" o que el mero desconocimiento de la norma ya presupone la actuación negligente ${ }^{46}$. Así, se deduce que en estos casos el deber de cuidado se ha positivizado, de modo que el incumplimiento de la norma constituye una conducta negligente ${ }^{47}$.

No obstante, es preciso reconocer que en estos casos los límites entre la responsabilidad por culpa y la responsabilidad objetiva se difuminan notablemente debido al elevadísimo estándar de diligencia exigido, en virtud del cual no solo se invierte la carga de la prueba (porque la mera realización de la conducta imputable constituye una prueba de cargo que debe ser rebatida por el administrado), sino que resulta muy difícil acreditar el actuar diligente, que requiere la existencia de un eximente de responsabilidad ${ }^{48}$. Sin embargo, la admisión de eximentes como el error, incluso en estos casos, permite entender que únicamente es posible sancionar por un comportamiento negligente ${ }^{49}$. Por tanto, si bien podría mantenerse que incluso en estos casos debe respetarse el principio de culpabilidad ${ }^{50}$, es preciso reconocer que estamos ante una de

46 Al respecto, tiene interés la explicación de Manuel Rebollo Puig, para quien en estos casos la infracción del deber objetivo de cuidado conllevaría la vulneración del deber subjetivo de cuidado, por lo que existiría una presunción de culpabilidad. Manuel Rebollo Puig, Potestad sancionadora..., óp. cit., pp. 636 y ss.

47 Tomás Cano Campos, "La culpabilidad...", óp. cit., pp. 87 y ss.; Alejandro Huergo Lora, óp. cit., pp. 387 y ss. También acepta esta posición Lucía Alarcón Sotomayor, "Los confines de las sanciones...", óp. cit., pp. 141 y 142.

48 En relación a la prueba de la culpabilidad, es conveniente recordar las palabras de Lucía Alarcón Sotomayor, para quien una vez que se verifica la existencia de la conducta típica y la participación del imputado (que exige la realización del hecho injusto con conocimiento y voluntad), para probar la culpabilidad, bastará que la autoridad quede convencida de que no concurren causas de exclusión o de justificación, las cuales le correspondería argumentar y probar al administrado. Según la autora, esto no implicaría presumir la culpabilidad, sino asegurarse de que concurre. LuCía AlARCÓN SOTOMAYOR, El procedimiento administrativo sancionador y los derechos fundamentales, Madrid: Civitas, 2007, pp. 403-404.

49 Así, por ejemplo, Manuel IzQuierdo CarRasco, "La culpabilidad y los sujetos responsables", en Derecho administrativo sancionador, Valladolid: Lex Nova, 2010, p. 255.

50 En contra, Alejandro Nieto cuestiona este planteamiento, que atribuye a "fórmulas de compromiso, más o menos ingeniosas, para intentar mantener la exigencia de culpabilidad en supuestos en los que realmente no tiene cabida", para lo cual "los juristas han tenido que retorcer su ingenio para justificar lo injustificable". Alejandro Nieto, óp. cit., p. 326. Sin embargo, el cambio en la Ley 40/2015 -que elimina la referencia a la "mera inobservancia" como un supuesto infractor y exige el dolo o culpa- ha supuesto un duro golpe para quienes defendían esta posición, lo que explica la posición tan crítica de autores como Miguel Casino Rubio a dicha modificación. Miguel Casino Rubio, óp. cit., p. 6. 
sus aplicaciones más complejas y matizadas, que cuando menos lo aproximan notablemente a la responsabilidad objetiva ${ }^{51}$.

En consecuencia, resulta esencial limitar los supuestos en donde podrían tipificarse este tipo de infracciones, las cuales deberían quedar limitadas a ciertas infracciones formales, en las cuales se persiguen infracciones de peligro estadístico ${ }^{52}$; es decir, que se protegen bienes jurídicos colectivos que podrían verse afectados si determinada conducta es repetida por todos ${ }^{53}$. En consecuencia, no tendría sentido pretender aplicar estas reglas en los casos en

51 A través de este trabajo, por tanto, se matiza una afirmación que hice en un trabajo previo. Víctor Sebastián Baca Oneto, "¿Responsabilidad subjetiva u objetiva en materia sancionadora? Una propuesta de respuesta a partir del ordenamiento peruano", en Derecho administrativo iberoamericano, IV Congreso Internacional de Derecho administrativo de Mendoza, Buenos Aires: Ediciones RAP, 2011, pp. 659 y ss. Así, en dicho trabajo se sostiene que en estos casos -en los cuales la infracción es meramente formal y se castiga por peligro estadístico debido a la vulneración de bienes jurídicos comunes- la responsabilidad puede ser objetiva. Sin embargo, en realidad lo que se quería indicar es que en estos casos la responsabilidad-que podría seguir llamándose subjetiva por un tema principista- es muy difícil de diferenciar de la responsabilidad objetiva, razón por la cual lo importante es establecer en qué casos sería posible esta excepción, que es lo que quería explicarse en dicho artículo. Así, se pretende establecer un régimen que resultaría injustificado en derecho penal, esto únicamente podría resultar admisible para castigar la vulneración de ciertos bienes jurídicos, que se protegen en la vía administrativa mejor que en la vía penal. Evidentemente, esto no significa aceptar que en derecho administrativo puedan castigarse conductas que no sean antijurídicas (porque no afecten o pongan en peligro ciertos bienes jurídicos), dado que la antijuridicidad es también un elemento esencial de las infracciones administrativas (Manuel Rebollo Puig, "Antijuridicidad", óp. cit., pp. 119 y ss.), sino que los bienes jurídicos pueden verse afectados por conductas que en sí mismas consideradas -incluso en abstracto- son inocuas, pero que repetidas por todos podrían afectarlos. No se castiga, por tanto, la pura desobediencia, sino que siempre se exige que la antijuridicidad de la conducta, aunque en este caso pueda fundamentarse en la afectación al bien jurídico protegido que se produciría si fuera repetida-impunemente-por todos.

52 En algún caso se ha sostenido que la referencia a las sanciones que se castigan a mérito de simple inobservancia en derecho administrativo español se refiere a las infracciones de peligro abstracto. Ángeles de Palma del Teso, "Principio de culpabilidad. Definición...", óp. cit., p. 208. Sin embargo, en la construcción que proponemos sería necesario dar un paso adicional, reservar la figura de las sanciones en las cuales la responsabilidad subjetiva se puede confundir con la objetiva para aquellos casos en donde se sanciona no solo por un peligro abstracto, sino incluso por un peligro estadístico.

53 Un antecedente de este interés por limitar los supuestos donde es posible utilizar estos supuestos de infracción, en Manuel Rebollo Puig, Potestad sancionadora..., óp. cit., pp. 632 y ss. Como afirma este autor, las singularidades que puedan existir respecto de la culpabilidad deben derivar, "en cada clase de infracciones administrativas según su bien jurídico protegido, del sector del ordenamiento y la actividad que presten el fundamento jurídico de la punición" (p. 633). Así, en el caso de las infracciones en materia de alimentación que analiza, la causa de sus peculiaridades radicaría en el bien jurídico protegido: la salud pública. Existiría un deber de no perturbar el orden público, que se vulneraría incluso mediante infracciones de mera conducta, que constituyan un peligro abstracto para dicho bien jurídico. 
donde no se cumple este requisito, como sucede, por ejemplo, en las infracciones consistentes en la presentación de información falsa o inexacta, en las cuales la infracción se persigue porque en sí misma ha generado un daño o es susceptible de generarlo ${ }^{54}$.

$\mathrm{Al}$ respecto, uno de los supuestos en donde tradicionalmente se ha pretendido aplicar la responsabilidad objetiva es la presentación de documentación falsa o inexacta en materia de contratos públicos. Si bien el texto de las resoluciones resultaba confuso, porque, al mismo tiempo que se sostenía que bastaba la presentación de documentos falsos o inexactos para que se configure la infracción, se indicaba que esto era así ya que los proveedores se encontraban obligados velar diligentemente por la veracidad formal y sustancial. ¿Es un supuesto de responsabilidad objetiva o acaso era un caso de responsabilidad subjetiva, en el cual se había fijado un estándar muy alto de diligencia ${ }^{55}$ ?

La respuesta la podemos encontrar en algunos casos controvertidos, como sucedió en el resuelto mediante la Resolución n. ${ }^{\circ}$ 633-2011-TC/OSCE, del 13 de abril de 2011. En este supuesto, la empresa Gilat to Home había contratado a una empresa especializada para que verificara los documentos de quien fue presentado como parte de la oferta técnica en un procedimiento de selección. Como estos documentos resultaron ser inexactos, se inició un procedimiento sancionador, aun cuando finalmente no se impuso una sanción, dado que se entendió que no se logró desvirtuar la presunción de inocencia ${ }^{56}$. Sin embargo, lo que realmente estaba en juego en este caso no era la presunción de inocencia, sino la existencia de culpa o no, dado que si Gilat to Home consiguió no ser castigada, fue porque se entendió que su conducta fue diligente.

En otros casos posteriores, el Tribunal del OSCE entendió que la labor de verificación hecha por un tercero no fue suficiente ${ }^{57}$, hasta el caso resuelto

54 La admisión de la posibilidad de imponer sanciones en derecho administrativo en estos casos no debe llevarnos a olvidar que el principio de intervención mínima no es una exclusividad del derecho penal, y que solo tiene sentido imponer castigos si se realiza una conducta antijurídica, que justifica la sanción. Sobre este tema, véase Lucía Alarcón Sotomayor, "Los confines de las sanciones...", óp. cit., pp. 135 y ss.

55 Sobre este tema, véase por ejemplo Carlos Santos Loyola, "Derecho administrativo sancionador y responsabilidad objetiva. Reflexiones a partir de algunas resoluciones del Tribunal de Contrataciones del Estado en procedimientos administrativos sancionadores por presentación de documentos falsos o información inexacta", en Modernizando el Estado para un país mejor. IV Congreso Nacional de Derecho Administrativo, Lima: Palestra, 2010, pp. 741 y ss.

56 La relación entre el principio de culpabilidad y la presunción de inocencia ha sido puesta de manifiesto en numerosas ocasiones. Al respecto, véase JORGE IVÁn Rincón, La potestad disciplinaria en el derecho administrativo, Buenos Aires: Universidad de Piura - IJ Editores, 2018, pp. 258 y ss.

57 Es el caso, por ejemplo, del expediente resuelto mediante la Resolución n. ${ }^{\circ}$ 0129-2016TC/OSCE, confirmada por la Resolución n. ${ }^{\circ}$ 211-2016-TC/OSCE. En este caso, Cosapi Data se defendió alegando que había contratado a otra empresa para que hiciera la revisión de 
por la Resolución n. ${ }^{\circ}$ 1977-2017-TC/OSCE, del 14 de septiembre de 2017, en la cual nuevamente admitió este criterio como un argumento de defensa, ahora sí referido a la ausencia de culpabilidad. Sin embargo, en este caso, el Tribunal del OSCE reconoció que no cabía aplicar responsabilidad objetiva porque era aplicable, como norma intermedia más favorable, lo dispuesto por la LPAG, pues el reconocimiento de la responsabilidad objetiva por la modificación de la Ley 30225 fue posterior a dicha norma. No obstante, lo cierto es que la LPAG establece claramente que, en los supuestos de presentación de documentación elaborada por un tercero, "el administrado puede acreditar su debida diligencia en realizar previamente a su presentación las verificaciones correspondientes y razonables". Es decir, se trata de un supuesto en el cual expresamente se ha previsto un mecanismo de justificación, por lo que no tendría sentido pretender aplicar un régimen objetivo de responsabilidad. En realidad, ni siquiera estaríamos en uno de los supuestos en los cuales podría llegar a confundirse la responsabilidad subjetiva con la objetiva, pues en este caso no estamos ante una infracción de peligro estadístico, ya que se trata de una conducta idónea por sí misma para poner en riesgo los bienes jurídicos protegido, como la concurrencia en los procedimientos sancionadores o la legalidad del procedimiento administrativo.

\subsection{EL PRINCIPIO DE CULPABILIDAD Y LAS INFRACCIONES DE LAS PERSONAS JURÍDICAS}

Por otro lado, respecto de las infracciones cometidas por las personas jurídicas, estas constituyen la mayor parte de las perseguibles en la vía administrativa. Sin embargo, en estos casos se cuestionaba la necesidad de acudir a una responsabilidad subjetiva, basada en la existencia de dolo o negligencia, si es que en el caso de las personas jurídicas no podía hablarse de culpabilidad, dado que carecen de voluntad. Es más, esta es justamente una de las razones por las que tradicionalmente se entendía que las personas jurídicas no eran pasibles de sanciones penales, en aplicación del clásico aforisma societas delinquere non potest. No obstante, a nivel doctrinal y jurisprudencial, se ha planteado que también respecto de las personas jurídicas resulta exigible el respeto del principio de culpabilidad, debate que ha transcurrido en paralelo con la discusión

sus documentos, pero en la primera resolución el Tribunal entendió que la diligencia de Cosapi había sido insuficiente. En la reconsideración, el Tribunal es incluso más duro, y sostiene que "En cuanto a la diligencia como eximente de responsabilidad [...] en el presente caso se acreditó la presentación de información inexacta por parte del Consorcio $[\ldots]$ el tipo infractor establecido por la normativa [...] no considera como elementos para la configuración de esta infracción, diligencia u otro factor similar, por lo que con la determinación de que la información es inexacta, que fue presentada y que estaba referida a cumplir un requisito u obtener ventaja, se configura la infracción". 
penal sobre la admisión de la responsabilidad de las personas jurídicas, lo que permitido enriquecerlo sustancialmente.

Así, en primer momento se sostuvo que dicho principio se respetaba, porque si bien falta el elemento volitivo en sentido estricto, las personas jurídicas tienen la "capacidad de infringir" (Sentencia del Tribunal Constitucional Español $246 / 1991)^{58}$. No obstante, esta interpretación del principio de culpabilidad para las personas jurídicas no fue del todo satisfactoria, porque esa "culpa" en el fondo no significaba nada. Como respuesta, han surgido al menos dos posiciones. De acuerdo a la primera, debido a que la persona jurídica actúa a través de sus representantes ${ }^{59}$, el dolo o culpa de aquella será el dolo o la culpa de estos ${ }^{60}$. Dado que la voluntad de la persona jurídica es la voluntad de sus representantes, la primera sería el sujeto activo de las infracciones, quien respondería directa (y no subsidiariamente) por sus actos. Así, no es que existan dos voluntades y dos culpas, sino una sola: la de la persona jurídica, que es la de los titulares de sus órganos ${ }^{61}$. En este sentido, si existiera una culpa in

58 Como ha explicado, por ejemplo, Blanca Lozano Cutanda, el reconocimiento de la responsabilidad de las personas jurídicas se produce a partir del reconocimiento de la capacidad de acción y, por tanto, de la "capacidad infractora" de las personas jurídicas. Las normas que se infringen están dirigidas a regular la actuación de las personas jurídicas, de modo que son ellas quienes las incumplen y, por tanto, quienes deberían ser sancionadas. El principio de culpabilidad se configura, en un primer momento, como equivalente a la capacidad de infringir el ordenamiento jurídico. Blanca Lozano Cutanda, "La responsabilidad de la persona jurídica en el ámbito sancionador administrativo (a propósito de la STC 246/91, de 19 de diciembre)", Revista de Administración Pública, n. ${ }^{\circ}$ 129, Madrid: Centro de Estudios Políticos y Constitucionales, 1992, pp. 214 y ss.

59 Nótese que es la responsabilidad por la actuación de los representantes (de los órganos de Administración), no de los trabajadores. De acuerdo a María José Gallardo Castillo, solo cabría imponer una sanción por los actos de los primeros, en tanto expresan la voluntad de la persona jurídica, pero no por los actos de los segundos, que únicamente justificarían una responsabilidad civil. María José Gallardo Castillo, óp. cit., p. 210, por nota. Al respecto, véase Manuel Rebollo Puig, "Responsabilidad sancionadora de personas jurídicas, entes sin personalidad y sus administradores", Revista de Derecho de la Universidad de Piura, n. ${ }^{\circ}$ 17, Piura: Universidad de Piura, 2016, pp. 230 y ss.

60 Manuel Rebollo Puig, Potestad sancionadora..., óp. cit., pp. 598 y ss.; y, con más detalle, del mismo autor, "Responsabilidad sancionadora de personas jurídicas...", óp. cit., pp. 231 y ss. Puede verse también, en el mismo sentido, Blanca Lozano Cutanda, "La responsabilidad de la persona jurídica...", óp. cit., p. 226; y, de la misma autora, "Persona jurídica, sujeto activo y responsable de las infracciones administrativas", en Diccionario de sanciones administrativas, Madrid: Iustel, 2010, pp. 604 y ss. La idea de que el dolo o culpa de la persona natural que imputa su acción a la persona jurídica sea evaluada para determinar la culpa de esta última ha llevado a Blanca Lozano a sostener que sancionar a ambas iría en contra del principio de non bis in idem (pp. 605 y ss.). En el mismo sentido, véase MANuel Rebollo Puig "Responsabilidad sancionadora de personas jurídicas...", óp. cit., p. 252; aunque reconoce que los tribunales no han aceptado supuesta contradicción.

61 Manuel Rebollo Puig, "Responsabilidad sancionadora de personas jurídicas...", óp. cit., p. 231. Este autor no comparte la teoría del déficit de organización, a la que se alude más adelante, porque los defectos estructurales que pudieran existir"se deberían a las personas 
vigilando, no sería de la persona jurídica por los actos de sus representantes, sino respecto de la "transgresión del ejercicio de la libertad empresarial"62.

Por otro lado, una segunda posición propone una noción de culpa adecuada a la realidad de las personas jurídicas. Una de estas teorías propone que la culpabilidad se identificaría con llamado "déficit de organización"63, de modo que su conducta sería reprochable cuando no se tomaron las medidas suficientes para impedir que se cometa una infracción. En este caso, la persona jurídica podría liberarse de responsabilidad cuando acredite una correcta organización a efectos de impedir la ocurrencia de dichos ilícitos, para lo cual adquieren gran relevancia las normas y criterios de compliance ${ }^{64}$. De acuerdo a esta posición, que

físicas y de nuevo quedaría sin explicación su traslado a la persona jurídica" (p. 232). En todo caso, únicamente podría servir para explicar la responsabilidad por actos de los empleados, pero no de los administradores.

62 Manuel Rebollo Puig, Potestad sancionadora..., óp. cit., p. 769.

63 Al respecto, véase Manuel Gómez Tomillo e Iñigo Sanz Rubiales, óp. cit., pp. 497 y ss. De acuerdo a Manuel Gómez Tomillo, los criterios a emplear para determinar si existe un déficit en la organización serían los siguientes: a) si ha habido o no una adecuada vigilancia, supervisión o control sobre el personal sin poder de dirección; b) si el hecho protagonizado por la persona jurídica es el resultado de un cúmulo de incorrectas actuaciones individuales de personas naturales insertas en la estructura ${ }_{i} \mathrm{c}$ ) si existen o no instrucciones expresas por parte de quien asume las tareas de dirección para evitar la conducta que origina la infracción, lo que se relaciona a los programas de cumplimiento; d) si existe alguna causa de disculpa, de inimputabilidad o error de prohibición en la persona física, aun cuando esto no necesariamente implicará la desaparición de la culpabilidad de la persona jurídica, pues podría ser incluso un indicio de la existencia del déficit de organización, e) el nivel jerárquico del autor individual de la conducta ${ }_{i}$ f) la existencia de un programa de cumplimiento serio, adoptado antes de la infracción; y g) el carácter doloso o imprudente de la persona física actuante pues la infracción será más grave cuando sea intencional que cuando sea imprudente. Manuel Gómez Tomillo, "Culpabilidad de las personas jurídicas por la comisión de infracciones administrativas y programas de cumplimiento", en Derecho administrativo sancionador, Lima: Instituto Pacífico, 2017, pp. 43 y ss. Sin embargo, sobre esto último, consideramos que la existencia de dolo por parte del autor podría constituir un indicio de falta de culpabilidad de la persona jurídica, si es que justamente es lo que permite poner de manifiesto que no hubo ningún déficit en la organización, que tomó todas las medidas necesarias para que no se realice la conducta, incluyendo el procedimiento de selección de sus empleados. OMar Mejía Patiño, Fundamentos de derecho administrativo sancionador, Bogotá: Universidad del Tolima - Grupo Editorial Ibáñez, pp. 204-205. No obstante, es cierto que, si la culpa o el dolo es del titular del órgano de administración, las probabilidades de alegar la falta de culpabilidad son muy escasas, lo que finalmente permite establecer un punto de encuentro entre las teorías de Rebollo Puig y Gómez To millo, pues para el segundo la jerarquía que ocupe el autor en la persona jurídica será uno de los criterios para determinar si existe déficit de organización.

64 Manuel Gómez Tomillo, "La culpabilidad de las personas jurídicas por la comisión de infracciones administrativas: especial referencia a los programas de cumplimiento", Revista de Administración Pública, n. ${ }^{\circ}$ 203, Madrid: Centro de Estudios Políticos y Constitucionales, 2017, pp. 67 y ss.; y, del mismo autor, "Culpabilidad de las personas jurídicas por la comisión de infracciones administrativas y programas de cumplimiento", óp. cit., pp. 41 y ss. La adopción de estos programas tendría, como regla general, carácter atenuante y, 
compartimos ${ }^{65}$, la culpa o dolo de las personas jurídicas no puede identificarse con la culpabilidad de las personas jurídicas (que tendrían una responsabilidad directa, no subsidiaria) ${ }^{66}$, aun cuando en todo caso es necesario tomar en cuenta que una persona jurídica solo responderá en la medida que haya una acción u omisión de una persona natural que se le pueda imputar, al haber sido realizada en un contexto o entorno societario ${ }^{67}$. Además, en este caso no es necesario identificar a la persona natural que habría actuado en representación de la persona jurídica, lo que constituiría un requisito para determinar si actuó con diligencia o no ${ }^{68}$, ni tampoco se limitaría la responsabilidad a los actos de los órganos de administración y no de los trabajadores. Finalmente, la carga de la prueba acerca de la no existencia del déficit de organización recaería en la persona jurídica, dado que es quien está en condiciones para hacerlo.

\section{A MODO DE CONCLUSIÓN}

La idea de construir un derecho administrativo sancionador que prescinda de los elementos de culpabilidad puede resultar atractiva, pues facilita la imposición de sanciones y simplifica el trabajo de la Administración pública. No han faltado argumentos teóricos para fundamentarlo, como es el carácter preventivo que se le atribuye a esta rama del ordenamiento jurídico. Sin embargo,

excepcionalmente, podría servir para exculpar. En el caso peruano, la regulación introducida por la Ley 30424 para la mal llamada responsabilidad "administrativa" de las personas jurídicas por la comisión de ciertos delitos y la posibilidad de liberarse si se ha implementado un programa de cumplimiento, pone de manifiesto que este mecanismo debería ser también extensible al derecho administrativo sancionador.

65 En derecho peruano, también reconduce la culpabilidad de las personas jurídicas al déficit de organización JuAN CaRlos MORÓN URBINA, Comentarios a la Ley del procedimiento administrativo general, t. II, 12. ${ }^{a}$ ed., Lima: Gaceta Jurídica, 2017, p. 450; VerónICA Rojas MONTES, óp. cit., pp. 13 y ss.

66 De acuerdo a Manuel Gómez Tomillo, en el caso de las personas jurídicas el dolo o la culpa no es un elemento del tipo (del delito o de la infracción), sino únicamente son elementos de la culpabilidad (como reprochabilidad subjetiva), donde se consideran los factores individuales de responsabilidad del autor. Dentro de este elemento puede tomarse en cuenta el dolo o la culpa de las personas naturales, como uno más de los elementos que conforman el juicio de culpabilidad. Manuel Gómez Tomillo, Introducción a la responsabilidad penal..., óp. cit., pp. 120 y ss. No obstante, esta afirmación no conlleva siempre, según Gómez Tomillo, la necesidad de individualizar al autor, dado que la culpa (al no ser un elemento del tipo) podría presumirse si concurren los elementos del tipo. De esta manera, podría entenderse que el dolo o la culpa forman parte del principio de tipicidad subjetiva sin necesidad de tener que individualizar al autor. MANuel GómEZ Tomillo e IÑIGO SANZ RUBIALES, óp. cit., pp. 375 y ss.,

67 Manuel Gómez Tomillo, Introducción a la responsabilidad penal..., óp. cit., pp. 53 y ss., en especial pp. 82 y ss.

68 Así, por ejemplo, Manuel Gómez Tomillo, "Culpabilidad de las personas jurídicas...", óp. cit., p. 40. 
si tenemos claro que las sanciones -al igual que las penas impuestas por los jueces-son castigos, mediante los cuales un mal se impone precisamente como tal ${ }^{69}$, nos vemos inequívocamente compelidos a reconocer que ambas son dos manifestaciones del mismo ius puniendi, cuyo ejercicio se justifica únicamente ante conductas que reúnen ciertas condiciones: debe existir una acción, la cual ha de ser típica, antijurídica y culpable.

A partir de esta constatación, pueden deducirse algunos principios que deben ser respetados cuando se impongan castigos, entre los cuales es preciso incluir al principio de culpabilidad, en su sentido más amplio. Es decir, solo cabe imponer sanciones si se respetan los principios de imputación por el hecho, personalidad de las penas, existencia de dolo o culpa (tipicidad subjetiva) y culpabilidad en sentido más estricto (como reprochabilidad subjetiva). Entre estos principios, seguramente el que más problemas genera es el de exigencia de dolo o culpa, porque durante mucho tiempo ha estado extendida la idea según la cual, en derecho administrativo sancionador, a diferencia de lo que sucede en derecho penal, resulta admisible la responsabilidad objetiva.

$\mathrm{Al}$ respecto, es indudable que existen diferencias entre el ámbito penal y el administrativo (las matizaciones a las que alude la doctrina), la más evidente de las cuales es que en el segundo no resulta exigible -como sucede en el primero como regla general- el dolo como un elemento del tipo infractor. No obstante, estas matizaciones en la aplicación de los principios del ius puniendi no deberían llevarnos a la negación de dichos principios, porque sería negar la unidad previamente enunciada. Al respecto, son dos los supuestos en donde la exigencia de culpa (entendida como negligencia) han sido más discutidos.

En primer lugar, en el caso de las sanciones de mera inobservancia, es cierto que la elevación de los estándares de diligencia exigibles en este caso, de modo que el mero incumplimiento de una norma permite entender que se ha cometido la infracción y presumir la negligencia, hace en ocasiones difícil diferenciar estos supuestos de aquellos en donde se predica una responsabilidad objetiva. Sin embargo, más allá de que sea posible aún en estos casos defender el alcance del principio de culpabilidad, lo más importante es delimitar adecuadamente el ámbito donde es posible tipificar infracciones de esta manera. En este sentido, lo que proponemos es que el uso de esta forma de tipificación no sea la regla sino la excepción, y deba justificarse en la naturaleza de los bienes protegidos en estos casos, que se podrían ver afectados por las infracciones de riesgo estadístico.

Por otro lado, en segundo lugar, respecto de las personas jurídicas, la admisión de la responsabilidad de estas no tiene que llevar a reconocer una responsabilidad objetiva, sin desconocer la exigencia de tipicidad subjetiva. En estos casos es necesario construir un concepto de culpabilidad que se adecue 
a las características de estos sujetos. Al respecto, lo que proponemos es entender que una persona jurídica será culpable cuando exista un déficit de organización, de modo que no se impida o incluso se favorezca la comisión de la infracción. No es necesario, por tanto, identificar a una persona natural que haya actuado con dolo o culpa, sino que esta se presumirá si existe un incumplimiento que le sea atribuible a la persona jurídica imputada, salvo que ésta pueda probar su actuar diligente.

\section{BIBLIOGRAFÍA}

Alarcón Sotomayor, LuCía. El procedimiento administrativo sancionador y los derechos fundamentales, Madrid: Civitas, 2007.

Alarcón Sotomayor, Lucía. "Los confines de las sanciones: en busca de la frontera entre derecho penal y derecho administrativo sancionador", Revista de Administración Pública, n. ${ }^{\circ}$ 195, Madrid: Centro de Estudios Políticos y Constitucionales, 2014.

Baca Oneto, Víctor Sebastián. "La naturaleza revocatoria y los límites de la extinción por incumplimiento de los títulos habilitantes", Derecho administrativo e integración europea. Estudios en bomenaje al profesor José Luis Martínez López-Muñiz, Madrid: Editorial Reus, 2017.

Baca Oneto, Víctor Sebastián. "La retroactividad favorable en derecho administrativo sancionador", Themis. Revista de Derecho, n. ${ }^{\circ}$ 69, Lima: Pontificia Universidad Católica del Perú, 2016.

Baca Oneto, Víctor Sebastián. Protección al consumidor, Lima: Indecopi, 2011.

Baca Oneto, Víctor Sebastián. "¿Responsabilidad subjetiva u objetiva en materia sancionadora? Una propuesta de respuesta a partir del ordenamiento peruano", en Derecho administrativo iberoamericano, IV Congreso Internacional de Derecho administrativo de Mendoza, Buenos Aires: Ediciones RAP, 2011.

Baca Oneto, Víctor Sebastián y Eduardo Ortega Sarco. "La extinción de la responsabilidad sancionadora en los supuestos de fusiones, aplicada a la contratación pública", Derecho y Sociedad, n. ${ }^{\circ} 45$, Lima: Asociación Civil Derecho y Sociedad de la Pontificia Universidad Católica del Perú, 2015.

Cano Campos, Tomás. "La culpabilidad y los sujetos responsables en las infracciones de tráfico", Documentación Administrativa, n. ${ }^{\circ}$ 284-285, Madrid: INAP, 2009.

Cano Campos, Tomás. "La potestad sancionadora de la Administración: una regulación fragmentaria, incompleta y perniciosa", Documentación Administrativa. Nueva Época, n. ${ }^{\circ}$ 2, Madrid: INAP, 2015. 
Cano Campos, Tomás. "¿Es una sanción la retirada del carnet por puntos?", Revista de Administración Pública, n. ${ }^{\circ}$ 184, Madrid: Centro de Estudios Políticos y Constitucionales, 2011.

Casino Rubio, Miguel. "La potestad sancionadora de la Administración y vuelta a la casilla de salida", Documentación administrativa, Nueva Época, n. ${ }^{\circ}$ 2, Madrid: INAP, 2015.

Cid Moliné, José. "Garantías y sanciones (Argumentos contra la tesis de la identidad de garantías entre las sanciones punitivas)", Revista de Administración Pública, n. ${ }^{\circ} 140$, Madrid: Centro de Estudios Políticos y Constitucionales, 1996.

Cueto Pérez, Miriam. "Los principios de la potestad sancionadora de la Administración pública. Tipicidad y responsabilidad", Documentación Administrativa, n. ${ }^{\circ} 280$ 281, Madrid: INAP, 2008.

Danós OrdóÑEZ, Jorge. "Notas sobre la potestad sancionadora de la Administración", Ius et Veritas, n. ${ }^{\circ}$ 10, Lima: Asociación Civil Derecho y Sociedad de la Pontificia Universidad Católica del Perú, 1994.

De Palma del Teso, Ángeles. El principio de culpabilidad en el derecho administrativo sancionador, Madrid: Tecnos, 1996.

De Palma del Teso, Ángeles. "La culpabilidad", Justicia Administrativa, número extraordinario, Valladolid: Lex Nova, 2001.

De Palma del Teso, Ángeles. "Principio de culpabilidad. Causas de exclusión y atenuación de la responsabilidad", en Diccionario de sanciones administrativas, Madrid: Iustel, 2010.

De Palma del Teso, Ángeles. "Principio de culpabilidad. Definición y aplicación a las personas físicas", en Diccionario de sanciones administrativas, Madrid: Iustel, 2010.

Gallardo Castillo, María José. Los principios de la potestad sancionadora administrativa. Teoría y práctica, Madrid: Iustel, 2008.

García de Enterría, Eduardo. "El problema jurídico de las sanciones administrativas", Revista Española de Derecho Administrativo, n. ${ }^{\circ}$ 10, Madrid: Civitas, 1976.

Gómez Tomillo, Manuel. "Culpabilidad de las personas jurídicas por la comisión de infracciones administrativas y programas de cumplimiento", en Derecho administrativo sancionador, Lima: Instituto Pacífico, 2017.

Gómez Tomillo, Manuel. "Derecho administrativo sancionador y derecho penal. Análisis del derecho positivo peruano. Especial consideración de los principios de legalidad, culpabilidad y oportunidad", Revista de Derecho de la Universidad de Piura, n. ${ }^{\circ}$ 4, Piura: Universidad de Piura, 2003. 
Gómez Tomillo, Manuel. Introducción a la responsabilidad penal de las personas jurídicas en el sistema español, Valladolid: Lex Nova, 2010.

Gómez Tomillo, Manuel. "La culpabilidad de las personas jurídicas por la comisión de infracciones administrativas: especial referencia a los programas de cumplimiento", Revista de Administración Pública, n. ${ }^{\circ}$ 203, Madrid: Centro de Estudios Políticos y Constitucionales, 2017.

Gómez Tomillo, Manuel e Iñigo Sanz Rubiales. Derecho administrativo sancionador. Parte general. Teoría y práctica del derecho penal administrativo, 4. ${ }^{a}$ ed., Madrid: Thomson Reuters - Aranzadi, 2017.

Huergo Lora, Alejandro. Las sanciones administrativas, Madrid: Iustel, 2007.

IzQuierdo Carrasco, Manuel. "La culpabilidad y los sujetos responsables", en Derecho administrativo sancionador, Valladolid: Lex Nova, 2010.

Laguna de Paz, José Carlos. "Culpabilidad y responsabilidad personal en las sanciones administrativas en materia de defensa de la competencia en el derecho europeo y español", Revista de Derecho de la Universidad de Piura, n. ${ }^{\circ}$ 18, Piura: Universidad de Piura, 2017.

Lozano Cutanda, Blanca. "La responsabilidad de la persona jurídica en el ámbito sancionador administrativo (a propósito de la STC 246/91, de 19 de diciembre)", Revista de Administración Pública, n. ${ }^{\circ}$ 129, Madrid: Centro de Estudios Políticos y Constitucionales, 1992.

Lozano Cutanda, Blanca. "Panorámica general de la potestad sancionadora de la Administración en Europa: 'despenalización' y garantía", Revista de Administración Pública, n. ${ }^{\circ}$ 121, Madrid: Centro de Estudios Políticos y Constitucionales, 1990.

Lozano Cutanda, Blanca. "Persona jurídica, sujeto activo y responsable de las infracciones administrativas", en Diccionario de sanciones administrativas, Madrid: Iustel, 2010.

Martín Retortillo, Sebastián. "Multas administrativas", Revista de Administración Pública, n. ${ }^{\circ}$ 79, Madrid: Centro de Estudios Políticos y Constitucionales, 1976.

Mejía Patiño, Omar. Fundamentos de derecho administrativo sancionador, Bogotá: Universidad del Tolima - Grupo Editorial Ibáñez, 2013.

Morón Urbina, Juan Carlos. Comentarios a la Ley del procedimiento administrativo general, t. II, 12. ${ }^{a}$ ed., Lima: Gaceta Jurídica, 2017.

Morón Urbina, Juan Carlos. "Los principios delimitadores de la potestad sancionadora de la Administración pública en la ley peruana", Revista Advocatus, n. ${ }^{\circ} 13$, Lima: Revista de los Alumnos de la Universidad de Lima, 2005. 
Nieto, Alejandro. Derecho administrativo sancionador, 5. ad., Madrid: Tecnos, 2012.

Ortega Sarco, Eduardo. "Adiós al principio de culpabilidad, en especial a la personalidad de las penas". Disponible en línea http://www.ius360.com/publico/ administrativo/adios-al-principio-de-culpabilidad-en-especial-a-la-personalidadde-las-penas/. [Consultado el 8 de agosto de 2018].

Parada VÁzQuez, Ramón. "El poder sancionador de la Administración y la crisis del sistema judicial penal", Revista de Administración Pública, n. ${ }^{\circ}$ 67, Madrid: Centro de Estudios Políticos y Constitucionales, 1972.

Pereira Chumbe, Roberto. "La potestad sancionadora de la Administración y el procedimiento administrativo sancionador en la Ley 27444", en Comentarios a Ley del Procedimiento administrativo general, Lima: ARA, 2001.

Ramírez Torrado, María Lourdes. "Consideraciones de la Corte Constitucional acerca del principio de culpabilidad en el ámbito sancionador administrativo", Revista de Derecho de la Universidad del Norte, n. ${ }^{\circ}$ 29, Barranquilla: Universidad del Norte, 2008.

Rebollo Puig, Manuel. "Antijuridicidad", en Diccionario de sanciones administrativas, Madrid: Iustel, 2010

Rebollo Puig, Manuel. "Derecho penal y derecho administrativo sancionador (principios comunes y aspectos diferenciadores)", en Diccionario de sanciones administrativas, Madrid: Iustel, 2010.

Rebollo Puig, Manuel. "El contenido de las sanciones", Revista Justicia Administrativa, número extraordinario, Valladolid: Lex Nova, 2001.

Rebollo Puig, Manuel. "Los principios de la potestad sancionadora en la Ley española del Régimen Jurídico del Sector Público", en Derecho administrativo sancionador, Lima: Instituto Pacífico, 2017.

Rebollo Puig, Manuel. "Los principios de responsabilidad, personalidad y culpabilidad en la determinación de los responsables de las infracciones", en Régimen jurídico básico de las Administraciones públicas. Libro Homenaje al profesor Luis Cosculluela, Madrid: Iustel, 2015.

Rebollo Puig, Manuel. Potestad sancionadora, alimentación y salud pública, Madrid: INAP, 1989.

Rebollo Puig, Manuel. "Responsabilidad sancionadora de personas jurídicas, entes sin personalidad y sus administradores", Revista de Derecho de la Universidad de Piura, n. ${ }^{\circ}$ 17, Piura: Universidad de Piura.

Rincón, Jorge IvÁn. La potestad disciplinaria en el derecho administrativo, Buenos Aires: Universidad de Piura - IJ Editores, 2018. 
Rojas Montes, Verónica. "La responsabilidad administrativa subjetiva de las personas jurídicas", Revista de Direito Econômico e Socioambiental,v. 8, n. ${ }^{\circ}$ 2, Curitiba: Pontifícia Universidade Católica do Paraná, 2017.

Santos Loyola, Carlos. "Derecho administrativo sancionador y responsabilidad objetiva. Reflexiones a partir de algunas resoluciones del Tribunal de Contrataciones del Estado en procedimientos administrativos sancionadores por presentación de documentos falsos o información inexacta", en Modernizando el Estado para un país mejor. IV Congreso Nacional de Derecho Administrativo, Lima: Palestra, 2010.

Santy Cabrera, Luiggi. "El principio de culpabilidad como responsabilidad subjetiva en el Derecho administrativo sancionador", Administración Pública \& Control, n. ${ }^{\circ} 44$, Lima: Editorial Gaceta Jurídica, 2017.

Shimabukuru Makikado, Roberto. "Reflexiones sobre el principio de culpabilidad y la responsabilidad administrativa objetiva", en Congreso Internacional de Derecho administrativo. Derecho administrativo en el siglo XXI, vol. I, Lima: Editorial Adrus, 2013.

SuAy Rincón, José. "Concepto de sanción", en Diccionario de sanciones administrativas, Madrid: Iustel, 2010.

Suay Rincón, José. Sanciones administrativas, Bolonia: Publicaciones del Real Colegio de España, 1989. 